\title{
Effect of Winter Flooding on Weeds, Soybean Yield, Straw Degradation, and Soil Chemical and Biochemical Characteristics
}

\author{
Clifford H. Koger ${ }^{1,2,3,4}$, Robert M. Zablotowicz ${ }^{2}$, Mark A. Weaver ${ }^{2,5}$, Melanie R. Tucker-Patterson ${ }^{2}$, \\ J. L. Krutz ${ }^{2,3}$, Timothy W. Walker ${ }^{3}$, Joe E. Street ${ }^{3}$ \\ ${ }^{1}$ Crop Genetics and Production Research Unit, USDA-ARS, Stoneville, USA; ${ }^{2}$ Crop Production Research Unit, USDA-ARS, Stone- \\ ville, USA; ${ }^{3}$ Delta Branch Experiment Station, Mississippi State University, Stoneville, USA; ${ }^{4}$ Syngenta 112 Meadowlark Lane, \\ Indianola, USA; ${ }^{5}$ Biological Control Pests Research Unit, USDA-ARS, Stoneville, USA. \\ Email: Mark.Weaver@ars.usda.gov
}

Received May $4^{\text {th }}, 2013$; revised June $7^{\text {th }}, 2013$; accepted June $25^{\text {th }}, 2013$

Copyright (C) 2013 Clifford H. Koger et al. This is an open access article distributed under the Creative Commons Attribution License, which permits unrestricted use, distribution, and reproduction in any medium, provided the original work is properly cited.

\begin{abstract}
Winter flooding of harvested rice fields attracts migratory waterfowl and may assist in degrading rice straw residue. Field studies were conducted between 2003 and 2005 in Stoneville, MS to evaluate the impacts of winter flooding of harvested rice fields on rice straw degradation, winter weeds, soybean yield, and soil biochemical and chemical properties. The experimental area each year consisted of a harvested rice field that remained no-till after harvest and that was dissected into 7.6- by $15-\mathrm{m}$ bays with constructed levees to accommodate winter flooding treatments. Flooding treatments (10-cm depth) consisted of: 1) flooded from mid-October to early March; 2) flooded mid-October to early January; 3) flooded mid-December to early March; 4) flooded mid-December to mid-January; and 5) no flood. Winter weeds were counted, biomass determined as well as residual rice straw before flooding and in early April of each year. Winter flooding reduced rice straw biomass $32 \%$ to $60 \%$ compared to $21 \%$ to $31 \%$ reduction for no winter flood with the longest flood duration resulting in the greatest loss of carbon and nitrogen from straw residues in both years. Winter flooding treatments reduced weed populations and weed biomass from $43 \%$ to $99 \%$ when compared to no flooding treatment. Soybean yields ranged from $3295 \mathrm{~kg} \cdot \mathrm{ha}^{-1}$ with the longest winter flooding regime to $4295 \mathrm{~kg} \cdot \mathrm{ha}^{-1}$ with no flooding. Significant reductions in soil nitrate levels were most consistent in the upper 0 to 2.5 -cm surface soil. Soil enzymatic activity (dehydrogenase and fluorescein diacetate hydrolysis) was increased by flooding in 2003, while minimal effects were found in the second year consistent with more anaerobic conditions attained in 2003 compared to 2004. Environmental benefits of accelerated straw decomposition and weed control is achieved by winter flooding; however, there are negative consequences of nitrogen losses and reduced soybean yield.
\end{abstract}

Keywords: Crop Growth; Crop Production; Flooded Rice; Rice; Soybean

\section{Introduction}

Rice (Oryza sativa L.) and soybean [Glycine $\max (\mathrm{L}$. Merr.] are commonly grown in rotation with one another in the lower Mississippi River Alluvial Flood Plain of Arkansas (AR), Louisiana (LA), and Mississippi (MS), USA (United States of America). Approximately 1.3, 0.5, and 0.9 million hectares of soybean and $0.5,0.2$, and 0.05 million hectares of rice, respectively, are grown annually in AR, LA, and MS (USDA, 2005). Rice and soybean are commonly grown in rotation because of both crops' adaptability to the clay soils of the midsouthern USA region. Grain yields and net returns for both crops are also increased when rice and soybean are grown in rotation [1].

Burning of rice straw following harvest has been widely used to facilitate planting the following crop and reduce disease potential. An alternative production practice in the midsouthern USA is to flood harvested rice fields in the late fall or early winter months (October to December) to provide wetland habitat for migratory waterfowl [2] and to enhance rice straw degradation so that the following soybean crop can be planted into minimal rice straw residue. Soybean emergence and plant fresh weight can be reduced by rice straw residues 
[4]. Winter flooding of harvested rice fields also reduces emergence and populations of winter weed species that, if present, necessitate chemical or mechanical control before spring planting of soybean $[5,6]$.

Concern for possible soybean yield reduction when grown in rotation with rice following a winter flood event has been noted by Mississippi State University extension personnel and soybean growers in the MS region of the lower Mississippi River Alluvial Flood Plain. These observations have been made visually, but no literature exists on whether a prolonged flood event following harvest of rice adversely effects yield of the following soybean crop. Other concerns for winter flooding are the potential for nutrient loss, especially accelerated nitrogen loss by denitrification and evolution of greenhouse gases, e.g., nitrous oxide and methane.

The Early Soybean Production System (ESPS) has been widely adopted by soybean growers in the midsouthern USA [7,8]. The ESPS consists of planting maturity group III, IV, or V cultivars in the months of March to early May. Planting early maturing cultivars during this time allows soybean plants to go through the reproductive growth stages, period of maximum water usage, prior to the typical summer drought period of the midsouth USA which generally extends from mid-July through mid-September $[8,9]$. The ESPS is compatible with a rice and soybean rotation system [10], however the impacts of winter flooding after rice harvest on winter weeds, yield of the soybean crop grown in rotation with rice, and soil microbial activity and community structure within the ESPS has not been investigated. Thus the objectives of this research were to determine the impacts of winter flooding after rice harvest on weeds, rice straw, soybean yield, and soil microbial activity and processes in the ESPS.

\section{Materials and Methods}

\subsection{Study Site and Crop Management Practices}

A field experiment was conducted in 2003-2004 in one field and again in an adjacent field in 2004-2005 at the USDA-ARS Southern Weed Science Research Unit Farm, Stoneville Mississippi (33 $26^{\prime} \mathrm{N}$ latitude). The soil type in the 2003 to 2004 experiment was a Dubbs silt loam (Typic Hapludalfs) with 33\% clay, 54\% silt, and $13 \%$ sand. The soil had a $\mathrm{pH}$ of 6.8 , total carbon and nitrogen content of 1.2 and $0.1 \%$, respectively, and a cation exchange capacity of $22.5 \mathrm{meq} \cdot 100 \mathrm{~g}^{-1}$ in the upper $15 \mathrm{~cm}$ of soil. In 2004 to 2005 experiment the soil was a Dundee silt loam soil (fine-silty, mixed thermic Aeric Ochraqualf) with $31 \%$ clay, $49 \%$ silt, and $20 \%$ sand. The soil had a $\mathrm{pH}$ of 7.1 , total carbon and nitrogen content of 1.3 and $0.1 \%$, respectively, and a cation exchange capacity of $14 \mathrm{meq} \cdot 100 \mathrm{~g}^{-1}$ in the upper $15 \mathrm{~cm}$ of soil. Specific total carbon and nitrogen content as well as nitrate and sulfate content of the soil in both experiments are presented in the results and discussion section.

The rice cultivar "Clearfield 161" was drilled in 19$\mathrm{cm}$-wide rows at $35 \mathrm{~kg} \mathrm{seed} \cdot \mathrm{ha}^{-1}$ in April of 2003 and 2004. Imazethapyr $\left(240 \mathrm{~g}\right.$ ae $\left.\cdot \mathrm{L}^{-1}\right)$ herbicide at $70 \mathrm{~g}$ ae ha $^{-1}$ was applied sequentially over-the-top of 2-leaf and 5-leaf rice to control weeds each year. The herbicide was applied using a carbon-dioxide-pressurized backpack sprayer calibrated to deliver 140 liter $\cdot \mathrm{ha}^{-1}$ at $193 \mathrm{kPa}$. A nonionic surfactant at $0.25 \% \mathrm{v} / \mathrm{v}$ was added to imazethapyr. Nitrogen $(\mathrm{N})$ fertilizer in the form of $34 \%$ ammonium nitrate was broadcast applied at $168 \mathrm{~kg} \mathrm{~N} \mathrm{ha}^{-1}$ at the five-leaf growth stage. Immediately after $\mathrm{N}$ application each year, a levee was constructed around the perimeter of the 0.4 ha experiment and a permanent 10 cm-deep flood was established. The flood was removed from the experiment two weeks prior to rice harvest. At maturity rice grain was harvested with a small plot combine.

Levees were constructed after rice harvest each year so that five different winter flooding regimes could be evaluated in a randomized complete block design. Flooding treatments consisted of: 1) flood mid-October thru mid-March; 2) flood mid-October thru mid-January; 3) flood mid-December thru mid-March; 4) flood mid-December thru mid-January; and 5) no flood. A sixth treatment consisting of no flood in the absence of rice straw residue (no flood/no rice straw) was included in an adjacent field area where rice was not grown. Floods were $10 \mathrm{~cm}$ deep and maintained throughout designated period by refilling bays with pumped groundwater as needed. Treatments were repeated four times in 4.5 - by 7.62-m plots.

\subsection{Weed and Rice Straw Assessments}

Winter weeds were counted in one $1-\mathrm{m}^{2}$ quadrat per plot just prior to initiation of flooding in mid-October or mid-December and again in early April 2004 and 2005. Additional weed counts were collected bi-weekly from mid-October thru mid-April in no flood and no flood/no rice straw plots by counting individual weed species from one permanent $1-\mathrm{m}^{2}$ quadrat per plot. Individual weeds were removed by hand immediately after counting in permanent quadrat areas. Additional weed counts were collected to determine when winter weeds emerged under no flooded conditions and the effect of rice straw on weed emergence. Weeds were counted by species, but counts were summed to comprise a total winter weed count each time weeds were counted from each quadrat. Total weed biomass was harvested by clipping all weeds at ground level from one $1-\mathrm{m}^{2}$ quadrat per plot in early April of each year. Weed biomass was collected from 
plot areas where no weed counts had previously been collected and was oven-dried at $30^{\circ} \mathrm{C}$ and weighed. Aboveground rice straw biomass was clipped at ground level from one $1-\mathrm{m}^{2}$ quadrat per plot in early-October and again from a different plot area in early-April. Rice straw biomass was oven-dried at $35^{\circ} \mathrm{C}$ and weighed.

\subsection{Soil and Straw Analysis}

Soils samples were collected from the same $1-\mathrm{m}^{2}$ quadrat that was used for rice straw biomass determination in October and April. From each plot, eight cores $(15 \mathrm{~cm}$ deep) were removed with a 5 -cm diameter probe. Cores were dissected into three portions so that analyses could be conducted on the $0-$ to $2.5-\mathrm{cm}, 2.5-$ to $5-\mathrm{cm}$, and $5-$ to $15-\mathrm{cm}$ soil depth segments. Soil for each segment was passed through a $2-\mathrm{mm}$ sieve and refrigerated at $5^{\circ} \mathrm{C}$ until analyzed for enzymatic activity. Two enzyme assays were conducted as indicators of microbial activity. Fluorecein diacetate hydrolytic enzyme activity $[11,12]$ and triphenyltetrazolim chloride (TTC) dehydogenase enzyme activity were measured using yeast extract as a carbon substrate [13]. Assays were modified using acetone as extractant as described by Weaver et al. [14] for wetland soils.

Following enzymatic analysis, soil was air dried, and the soil was milled twice through a 2-mm sieve in a Wiley Mill. Soil was ground in a mortar and pestle and weighed prior to carbon and nitrogen analysis. Total carbon and nitrogen content of soil and straw were determined using a Flash EA 112 elemental analyzer (C.E. Elantec, Lakewood, NJ) with all samples analyzed in triplicate as described elsewhere [15]. Soils (10 g) were extracted with $20 \mathrm{~mL}$ of distilled water, centrifuged $(10 \mathrm{~min}, 8000 \mathrm{~g})$ and the supernatant filtered. The water extractable anions (nitrate, sulfate and phosphate) were determined using an ICS 2000 Dionex ion chromatography Dionex Corp., Sunnyvale, CA) as described elsewhere [15]. Separation of anions was performed using an IonPac AS18 hydroxide selective anion exchange column, and data analyzed using Chromeleon software (Dionex Corp., Sunnyvale, CA).

\subsection{Soybean Management and Yield}

The glyphosate-resistant (GR) soybean cultivar "Pioneer 94B73" was planted on April 14, 2004 and the GR cultivar "Dekalb 46-51" was planted on April 19, 2005 in all plots except the no flood/no rice straw plots. Soybean was planted $2.5-\mathrm{cm}$ deep in eight $45-\mathrm{cm}$-wide rows over the entire plot length. Soybean was planted at $16 \mathrm{seed} \cdot \mathrm{m}^{-1}$ row using a John Deere vacuum planter configured so that four planter units would plant between the tractor tires (spaced $203 \mathrm{~cm}$ apart) and two planter units would plant on the outside of each tire. The space between planter units to accommodate for tractor tires was $70 \mathrm{~cm}$. Emerged soybean plants were counted four weeks after planting in two 1-m lengths from each of the four center rows per plot. Glyphosate was applied at $860 \mathrm{~g}$ ae $\cdot \mathrm{ha}^{-1}$ two weeks prior to planting soybean and three times throughout the soybean growing season each year to control weeds. Pyraclostrobin and Lamda-cyhalothrin were applied at 110 and $36 \mathrm{~g}$ ai ha ${ }^{-1}$, respectively, to soybean in the R3 reproductive growth stage [16] to manage foliar diseases and insects. Pesticides were applied using a carbon-dioxide-pressurized backpack sprayer calibrated to deliver 140 liter $\cdot \mathrm{ha}^{-1}$ at $193 \mathrm{kPa}$. Soybean was furrow-irrigated in the tire wheel tracks of each plot as needed. The middle four soybean rows of each plot were harvested at maturity with a small plot combine and soybean yields were adjusted to $13 \%$ moisture.

\subsection{Statistical Methods}

Data were tested for homogeneity of variance by plotting residuals. An arcsine square root transformation was performed before analysis but did not improve variance homogeneity. Thus, non-transformed data were used in analysis and presentation. Data were subjected to Analysis of Variance using the general linear model procedure in SAS [17]. Means were separated using Fisher's protected LSD test at $\mathrm{P}<0.05$. Data were averaged across years (as main effect means) when interactions were not significant and are presented for interactions where appropriate.

\section{Results and Discussion}

\subsection{Weed Populations and Biomass}

Population and biomass data were averaged across years due to no interactions or effect involving year. Rice straw residue reduced emergence of winter weeds when compared to emergence in the absence of rice straw residue (Figure 1). Winter weeds emerged as early as October and as late as March in both years. Peak emergence of winter weeds was between October and December in both years. There were no differences in weed emergence patterns across years even though rainfall patterns were noticeably different. The cumulative 30 year average rainfall amount for the months of October thru March in Stoneville, MS is $63.5 \mathrm{~cm}$. The amount of rainfall received in Stoneville, MS was $63 \mathrm{~cm}$ from October 1, 2003 to March 31, 2004 and $89 \mathrm{~cm}$ from October 1, 2003 to March 31, 2005, respectively.

Winter weed species that emerged and contributed to populations and biomass were annual bluegrass (Poa annua L.), henbit (Lamium amplexicaule L.), mouseear chickweed (Cerastium vulgatum L.), and shepherd's purse (Capsella bursa-pastoris L.). Cumulatively, these 


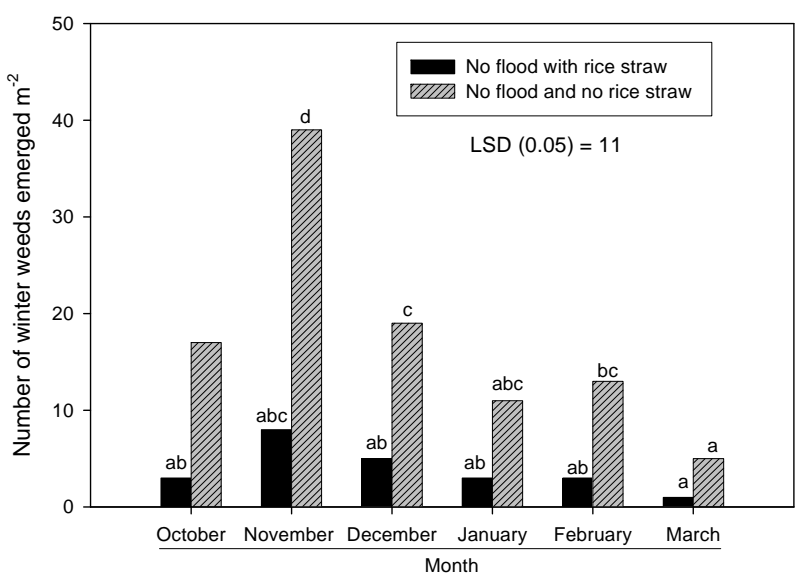

Figure 1. Emergence of winter weeds by month in no flood with rice straw and no flood no rice straw treatments. Number of weeds emerged by month in each plot were summed. Weeds present were annual bluegrass, henbit, mouseear chickweed, and shepherd's purse. Bars with the same letter are not different $(P \geq 0.05)$ according to $\mathrm{LSD}_{0.05}$.

weed species accounted for more than $98 \%$ of all weed populations and biomass in both years. Cumulative weed populations were decreased by winter flooding compared to no flooding in both years. Weed biomass was reduced by greater than $66 \%$ in all flooding regimens and by greater than $96 \%$ for treatments initiated in October (Table 1). No winter weeds were present in April 2004 when flooding was imposed in October prior to emergence of any weeds. However, when initiation of winter flooding was delayed until December after weed emer gence, weeds were still present in April. Thus, winter flooding did not kill weeds that emerged prior to flooding, but did prohibit weeds from emerging when flooding was initiated prior to flooding. Flooding prior to weed emergence can result in weed-free conditions and a clean seed-bed for planting the following crop.

Winter weeds emerged in October of 2004 after establishment of mid-October flood (Table 1). Emergence of weeds in October after flood establishment was attributed to the difficulty in maintaining a permanent flood in plots between mid-October of 2004 thru mid-March of 2005. Water was added to bays every two to three days, but soil was believed to be more porous and seepage through levees was constant in the entire experimental area for the 2004 thru 2005 experiment. Anaerobic conditions at the soil surface may have been compromised during desired flooded periods of the 2004 thru 2005 experiment. Winter weed populations were reduced significantly in flooded plots compared to no flooded plots in 2004 thru 2005 experiment even though maintained flood was difficult to obtain. Winter weeds that emerged in fluctuating flooded conditions (mid-October flood) appeared to be smaller than weeds that emerged under aerobic conditions prior to December flooding and then flooded be- ginning in mid-December.

Winter weed biomass was significantly lower regardless of flood treatment when compared to no flood in both years, with no difference across years (Table 1).

Previous research has shown that anaerobic conditions as a result of flooded soil can reduce biomass and overall plant health [18]. Anoxia as a result of flooded soil conditions can also reduce germination and emergence of monocot and dicot species [19,20]. Research has found that the inhibition of $\alpha$-amylase synthesis under anaerobic conditions can prohibit seed germination [19]. Reduction in plant biomass under anaerobic flooded conditions starves shoot and root tissue of oxygen, resulting in cessation of aerobic respiration, dropping levels of energy-rich adenylates, and decline in ion uptake and transport [20].

\subsection{Effects of Flooding on Rice Straw}

Data are presented by year due to significant year effect on straw degradation. An average of $6550 \mathrm{~kg} \cdot \mathrm{ha}^{-1}$ of rice straw residue was present in early October of each year prior to flood initiation. Flooding reduced levels of residual rice straw biomass when compared to plots not flooding (Table 2). Flooding beginning in mid-October and a three-month flood beginning in mid-December reduced rice straw residue in 2003 thru 2004 by $60 \%$ and $56 \%$, respectively, compared to no flooding (31\%). All flood treatments reduced rice straw residue in 2004 thru 2005 experiment when compared to no flooding, but not to the extent as in the 2003 thru 2004 experiment. Hill et al., [21] also reported winter flooding enhances decomposition of rice straw residue as compared to no flooding.

Table 1. Effects of winter flooding on weed populations and winter weed dry biomass ${ }^{\mathrm{a}}$.

\begin{tabular}{cccc}
\hline & \multicolumn{2}{c}{ Weed Population } & Weed dry biomass \\
\cline { 2 - 3 } Flood duration & $2004 \quad 2005$ & \\
\cline { 2 - 3 } & \multicolumn{2}{c}{$\mathrm{Ng} \mathrm{m}^{-2} \cdot \mathrm{ha}^{-1}$} \\
\hline $\begin{array}{c}\text { mid-Oct thru } \\
\text { mid-March } \\
\text { mid-Oct thru } \\
\text { mid-Jan }\end{array}$ & 0 & 11 & 9 \\
$\begin{array}{c}\text { mid-Dec thru } \\
\text { mid-March } \\
\text { mid-Dec thru } \\
\text { mid-Jan }\end{array}$ & 14 & 28 & 48 \\
$\begin{array}{c}\text { No Flood } \\
\text { LSD (0.05) }\end{array}$ & 38 & 63 & 288 \\
\hline
\end{tabular}

${ }^{\mathrm{a} C u m u l a t i v e}$ winter weed population and dry biomass was determined in early April, two weeks after removal of mid-march flood. Number of weeds emerged in each plot were summed for population estimate. Weeds present were annual bluegrass, henbit, mouseear chickweed, and shepherd's purse. ${ }^{\mathrm{b}}$ Means within a column are separated according to LSD value at $\mathrm{P}=0.05$. 
Table 2. Effects of winter flooding on reduction of rice straw biomass and loss of nitrogen and carbon from straw in 2004 and 2005.

\begin{tabular}{|c|c|c|c|c|c|c|}
\hline \multirow{2}{*}{$\begin{array}{l}\text { Flood } \\
\text { duration }\end{array}$} & \multicolumn{2}{|c|}{$\begin{array}{c}\text { Straw } \\
\text { reduction } \\
\text { ( }(\%)\end{array}$} & \multicolumn{2}{|c|}{$\begin{array}{c}\text { Nitrogen loss } \\
\left(\mathrm{kg} \cdot \mathrm{ha}^{-1}\right)\end{array}$} & \multicolumn{2}{|c|}{$\begin{array}{c}\text { Carbon loss }{ }^{\mathrm{c}} \\
\left(\mathrm{kg} \cdot \mathrm{ha}^{-1}\right)\end{array}$} \\
\hline & 2004 & 2005 & 2004 & 2005 & 2004 & 2005 \\
\hline $\begin{array}{l}\text { mid-Oct thru } \\
\text { mid-March }\end{array}$ & 60 & 42 & 43 & 65 & 1795 & 1402 \\
\hline $\begin{array}{l}\text { mid-Oct thru } \\
\text { mid-Jan }\end{array}$ & 54 & 35 & 23 & 44 & 1701 & 936 \\
\hline $\begin{array}{l}\text { mid-Dec thru } \\
\text { mid-March }\end{array}$ & 56 & 32 & 11 & 38 & 1662 & 964 \\
\hline $\begin{array}{l}\text { mid-Dec thru } \\
\text { mid-Jan }\end{array}$ & 38 & 32 & 5 & 49 & 1234 & 1032 \\
\hline No Flood & 31 & 21 & -3 & 46 & 917 & 981 \\
\hline $\operatorname{LSD}(0.05)$ & 14 & 8 & 9 & 8 & 223 & 176 \\
\hline
\end{tabular}

${ }^{\text {a }}$ Percent reduction of rice straw based on aboveground rice straw present in early October prior to mid-October flooding as compared to amount present in early April two weeks after removal of mid-March flood. ${ }^{b}$ Percent reduction of total nitrogen present in rice straw based on aboveground rice straw present in early October prior to mid-October flooding as compared to amount present in early April two weeks after removal of mid-March flood. ${ }^{c}$ Percent reduction of total carbon content of rice straw based on aboveground rice straw present in early October prior to mid-October flooding as compared to amount present in early April two weeks after removal of mid-March flood. ${ }^{\mathrm{d}}$ Means within a column are separated according to LSD value at $\mathrm{P}=0.05$

Amounts of rice straw residue in these experiments were similar to those previously reported in the literature [22].

The greatest loss in nitrogen and carbon content of rice straw was under the longest flood duration (Table 2). In the 2003 to 2004 experiment, three of the four flooding regimes resulted in loss of nitrogen in straw compared to no flood treatment, and all four flooding regimes resulted in significant carbon loss. In the 2004 to 2005 experiment, only the longest duration of flooding resulted in nitrogen or carbon loss from straw residues compared to none flood treatment. Less reduction of rice straw residue in the second experiment was attributed to the difficulty in maintaining a consistent flood, as discussed previously.

\subsection{Effects of Flooding on Soil Enzyme Activity and Chemical Properties}

Soil enzymatic activity was differentially affected by flooding with respect to year (Table 3), thus data are presented by year. In 2004, the longest flooding regime increased FDA hydrolytic activity compared to the nonflooded control in all three soil depths, and TTC-dehydrogenase activity was greater in the two lowest soil depths when compared to non-flooded soil. In the 2004 to 2005 experiment, three flooding regimes decreased FDA hydrolytic activity in the surface 0 to $2.5 \mathrm{~cm}$ of soil, while flooding had no effect on hydrolytic activity in the lower depths. In contrast, dehydrogenase activity was unaffected by flooding. Less enzyme activity response in 2004 to 2005 when compared to responses in 2003 to 2004 was attributed to the difficulty in maintaining a continuous flood in the 2004 to 2005 experiment as discussed previously.

Tucker-Patterson [23] reported that flooding longer than 3 months increased both FDA hydrolysis and TTCdehydrogenase activity in the upper 0 to $2.5 \mathrm{~cm}$ of soil in most monthly samples taken in 2003 to 2004 experiment. The elevated microbial activity was associated with a microbial community structure that shifted to a reduced fungal and increased fermentative bacterial composition under anaerobic, flooded conditions. FDA activity is associated with microbial biomass. The activity of FDA is subsequently regulated by the abundance of soil microorganisms and substrate to support their activity. Accelerated degradation of rice residues should provide additional labile soil carbon at the soil surface to support increased soil enzyme activity as was observed in the spring of 2004.

Data for soil chemical properties are presented by year due to significant year effect and interactions. There was no significant effect of flooding on total carbon and nitrogen content of soil following flooding, as some difference in these two parameters were observed before flooding (data not shown). In both years, the lowest levels of soil nitrate in the surface 0 to $2.5 \mathrm{~cm}$ were in the earliest flood regimes (Table 4). In 2004, three flooding regimes decreased nitrate in the 2.5 to $5.0 \mathrm{~cm}$ soil depth. In April of 2005, the highest nitrate level was found in the longest flooding regime in the 5 - to $15-\mathrm{cm}$ depth. The lowest level of water extractable sulfate was found in the two early flooded treatments in the surface soil in April 2004. However, in the 5- to $15-\mathrm{cm}$ depth, the highest sulfate concentration was in the non-flooded soil. In 2005 the highest water soluble sulfate was present in the two lower depths of soil that was under the longest flood. A low level of water soluble phosphorous was found, with minimal differences between treatments.

Soil electrical conductivity was much higher in soils of experiment 1 (2003-2004) compared to experiment 2 (2004-2005) (Table 5). Flooding significantly lowered electrical conductivity by as much as $31 \%$ in April 2004 , while no significant effect of flooding observed at any depth in April of 2005. Measurements of EC can provide a simple assessment of availability of nutrients under flooded conditions [24] and is used as an indicator of soil fertility in landscape mapping [25].

\subsection{Soybean Yield}

Soybean yields were averaged across years due to no effect or interaction involving year. Soybean yields were reduced by a flood established in October, but not floods 
Table 3. Effect of winter flooding on two soil enzymes activities: fluorescein diacetate hydrolysis and triphenyl tetrazolim chloride-dehydrogense activity.

\begin{tabular}{|c|c|c|c|c|c|c|c|c|}
\hline \multirow{2}{*}{ Flood dutarion } & \multicolumn{4}{|c|}{$\begin{array}{l}\text { Fluorescein diacaetate hydrolysis } \\
\left(\mathrm{nmol} \text { fluorescein formed } \mathrm{g}^{-1} \cdot \text { soil }^{-1} \mathrm{~h}^{\mathrm{a}}\right)^{\mathrm{a}}\end{array}$} & \multicolumn{4}{|c|}{$\begin{array}{c}\text { Tetrazolium chloride dehydrogenase } \\
\left(\text { nmol triphenyl formazan fomed } \mathrm{g}^{-1} \cdot \mathrm{soil}^{-1} \cdot \mathrm{h}^{-1}\right)^{\mathrm{a}}\end{array}$} \\
\hline & $\begin{array}{l}\text { October } \\
2003\end{array}$ & $\begin{array}{l}\text { April } \\
2004\end{array}$ & $\begin{array}{l}\text { October } \\
2004\end{array}$ & $\begin{array}{l}\text { April } \\
2005\end{array}$ & $\begin{array}{l}\text { October } \\
2003\end{array}$ & $\begin{array}{l}\text { April } \\
2004\end{array}$ & $\begin{array}{l}\text { October } \\
2004\end{array}$ & $\begin{array}{l}\text { April } \\
2005\end{array}$ \\
\hline \multicolumn{9}{|l|}{0 - to $2.5 \mathrm{~cm}$ soil depth } \\
\hline mid-Oct thru mid-March & 53 & 57 & 81 & 18 & 63 & 64 & 51 & 51 \\
\hline mid-Oct thru mid-Jan & 57 & 44 & 72 & 17 & 59 & 59 & 48 & 44 \\
\hline mid-Dec thru mid-March & 59 & 49 & 73 & 17 & 57 & 67 & 48 & 44 \\
\hline mid-Dec thru mid-Jan & 57 & 44 & 65 & 34 & 56 & 70 & 47 & 48 \\
\hline No Flood & 54 & 46 & 68 & 46 & 61 & 70 & 44 & 60 \\
\hline $\operatorname{LSD}(0.05)$ & 8 & 7 & 10 & 15 & 5 & NS & 6 & NS \\
\hline \multicolumn{9}{|l|}{0 - to $2.5 \mathrm{~cm}$ soil depth } \\
\hline mid-Oct thru mid-March & 42 & 52 & 62 & 25 & 79 & 57 & 73 & 72 \\
\hline mid-Oct thru mid-Jan & 52 & 46 & 49 & 28 & 81 & 49 & 62 & 61 \\
\hline mid-Dec thru mid-March & 46 & 43 & 53 & 33 & 72 & 46 & 69 & 53 \\
\hline mid-Dec thru mid-Jan & 47 & 50 & 47 & 36 & 70 & 56 & 63 & 56 \\
\hline No Flood & 39 & 35 & 49 & 40 & 77 & 37 & 60 & 66 \\
\hline $\operatorname{LSD}(0.05)$ & 8 & 4 & 11 & 12 & NS & 5 & 8 & NS \\
\hline \multicolumn{9}{|l|}{0 - to $2.5 \mathrm{~cm}$ soil depth } \\
\hline mid-Oct thru mid-March & 47 & 57 & 36 & 16 & 49 & 51 & 52 & 43 \\
\hline mid-Oct thru mid-Jan & 53 & 44 & 33 & 18 & 49 & 39 & 48 & 44 \\
\hline mid-Dec thru mid-March & 45 & 46 & 35 & 14 & 46 & 40 & 48 & 44 \\
\hline mid-Dec thru mid-Jan & 49 & 43 & 33 & 14 & 46 & 32 & 47 & 49 \\
\hline No Flood & 47 & 56 & 32 & 13 & 50 & 29 & 47 & 44 \\
\hline $\operatorname{LSD}(0.05)$ & 10 & 7 & NS & NS & 5 & 3 & 6 & NS \\
\hline
\end{tabular}

${ }^{\mathrm{a}}$ Means within a column for a given depth are separated according to LSD value at $\mathrm{P}=0.05$.

Table 4. Water extractable anions of soils collected at various depths, prior to soybean planting in April 2004 and 2005.

\begin{tabular}{|c|c|c|c|c|c|c|}
\hline \multirow{3}{*}{ Flood dutarion } & \multicolumn{3}{|c|}{ April 2004} & \multicolumn{3}{|c|}{ April 2005} \\
\hline & \multicolumn{6}{|c|}{ Anion concentration $\left(\mathrm{mg}\right.$ anion $\cdot \mathrm{kg}^{-1}$ soil) } \\
\hline & Nitrate & Sulfate & Phosphate & Nitrate & Sulfate & Phosphate \\
\hline \multicolumn{7}{|l|}{0 - to $2.5 \mathrm{~cm}$ soil depth } \\
\hline mid-Oct thru mid-March & 3.5 & 4.5 & 1.2 & 3.3 & 4.8 & $<0.5$ \\
\hline mid-Oct thru mid-Jan & 4.4 & 2.5 & 2.4 & 4.5 & 4.6 & $<0.5$ \\
\hline mid-Dec thru mid-March & 5.1 & 11.2 & 1.5 & 10.5 & 1.2 & $<0.5$ \\
\hline mid-Dec thru mid-Jan & 14.7 & 32.6 & 1.1 & 11.5 & 1.0 & $<0.5$ \\
\hline No Flood & 16.1 & 21.4 & 0.9 & 8.0 & 1.4 & $<0.5$ \\
\hline $\operatorname{LSD}(0.05)$ & 8 & 10 & 1.2 & 5.4 & 3.6 & NS \\
\hline \multicolumn{7}{|l|}{0 - to $2.5 \mathrm{~cm}$ soil depth } \\
\hline mid-Oct thru mid-March & 1.7 & 1.0 & $<0.5$ & 9.3 & 5.4 & $<0.5$ \\
\hline mid-Oct thru mid-Jan & 1.7 & 0.6 & $<0.5$ & 9.5 & 3.6 & $<0.5$ \\
\hline mid-Dec thru mid-March & 2.5 & 1.2 & $<0.5$ & 11.4 & 1.9 & $<0.5$ \\
\hline mid-Dec thru mid-Jan & 3.7 & 1.4 & $<0.5$ & 5.1 & 1.2 & $<0.5$ \\
\hline No Flood & 3.0 & 1.3 & $<0.5$ & 5.1 & 1.2 & $<0.5$ \\
\hline $\operatorname{LSD}(0.05)$ & 1.1 & 0.6 & NS & 5.0 & 1.9 & NS \\
\hline \multicolumn{7}{|l|}{0 - to $2.5 \mathrm{~cm}$ soil depth } \\
\hline mid-Oct thru mid-March & 0.7 & 0.5 & $<0.5$ & 7.7 & 2.5 & $<0.5$ \\
\hline mid-Oct thru mid-Jan & 1.0 & 0.6 & $<0.5$ & 4.5 & 1.4 & $<0.5$ \\
\hline mid-Dec thru mid-March & 0.7 & 2.8 & $<0.5$ & 5.4 & 0.7 & $<0.5$ \\
\hline mid-Dec thru mid-Jan & 1.1 & 1.3 & $<0.5$ & 4.5 & 0.8 & $<0.5$ \\
\hline No Flood & 1.3 & 3. & $<0.5$ & 3.2 & 0.9 & $<0.5$ \\
\hline $\operatorname{LSD}(0.05)$ & ns & 1.4 & NS & 2.8 & 0.8 & NS \\
\hline
\end{tabular}

${ }^{\mathrm{a}}$ Means within a column for a given depth are separated according to LSD value at $\mathrm{P}=0.05$. 
Table 5. Effect of flooding on soil electrical conductivity.

\begin{tabular}{|c|c|c|}
\hline \multirow{2}{*}{ Flood duration } & \multicolumn{2}{|c|}{$\begin{array}{l}\text { Electrical conductivity } \\
\left(\mathrm{mS} \cdot \mathrm{cm}^{-1}\right)\end{array}$} \\
\hline & April 2004 & April 2005 \\
\hline \multicolumn{3}{|l|}{0 - to 2.5 -cm depth } \\
\hline mid-Oct thru mid-March & 977 & 161 \\
\hline mid-Oct thru mid-Jan & 905 & 201 \\
\hline mid-Dec thru mid-March & 977 & 145 \\
\hline mid-Dec thru mid-Jan & 1393 & 175 \\
\hline No Flood & 1412 & 210 \\
\hline $\operatorname{LSD}(0.05)$ & 269 & NS \\
\hline \multicolumn{3}{|l|}{ 2.5- to 5-cm depth } \\
\hline mid-Oct thru mid-March & 823 & 181 \\
\hline mid-Oct thru mid-Jan & 725 & 134 \\
\hline mid-Dec thru mid-March & 931 & 147 \\
\hline mid-Dec thru mid-Jan & 978 & 177 \\
\hline No Flood & 1096 & 166 \\
\hline $\operatorname{LSD}(0.05)$ & 102 & NS \\
\hline \multicolumn{3}{|l|}{ 2.5- to 5-cm depth } \\
\hline mid-Oct thru mid-March & 603 & 161 \\
\hline mid-Oct thru mid-Jan & 611 & 201 \\
\hline mid-Dec thru mid-March & 675 & 144 \\
\hline mid-Dec thru mid-Jan & 775 & 175 \\
\hline No Flood & 835 & 200 \\
\hline $\operatorname{LSD}(0.05)$ & 66 & NS \\
\hline
\end{tabular}

established in December (Figure 2). Floods established in October reduced soybean yields $16 \%$ to $24 \%$ when compared to yields in the non-flooded treatment (4295 $\left.\mathrm{kg} \cdot \mathrm{ha}^{-1}\right)$. Reduction in yield was not due to soybean stand establishment, as the plant population $\left(304,800\right.$ plants $\left.\cdot \mathrm{ha}^{-1}\right)$ was consistent across all plots each year.

Decreased soybean yields may be attributed to flooded soil syndrome (FSS). The term FSS was coined after growers and extension personnel in the Midwestern USA discovered P-deficiencies on corn and soybean after the floods of 1993. The plant symptoms were very similar to that of corn and soybean grown after soils were fallow [26,27]. Phosphorus deficiencies severely inhibited corn yields and, to a lesser extent, affected soybean yields. Soil test P levels ironically were equal to or higher in those soils that had been inundated with water compared to soils that were not. Shahandeh et al. [28] showed that because of the flooding and drying cycles common in rice production, current soil tests methods do not accu- rately predict plant available $\mathrm{P}$. It has been shown that amorphous Fe compounds sorb P greater than crystalline forms of Fe. Furthermore, the solubility of amorphous Fe-P compounds is less than crystalline compounds, especially in aerobic soil conditions. Nutrient uptake data were collected during the 2005 growing season and Puptake was $27 \%$ greater for the no-flood treatment compared to when the field was saturated from October through March.

Vesicular-arbuscular mychorrizae (VAM) colonization has been proven to improve plant uptake of $\mathrm{P}$ and other nutrients [29]. Ellis [27], Wetterauer and Killorn [26], and Lohry and Fixen [30] have documented that the reduction in colonization of VAM after fallow or flooding events have contributed to $\mathrm{P}$ deficiencies in corn and soybean.

A second factor that may also have affected soybean yield is nitrogen loss from extended flooding. Both lower soil nitrate in the surface soil and greater loss of nitrogen from rice straw indicates less initially available soil nitrogen at time of planting. The use of starter nitrogen has been suggested as a method to enhance growth and yield of late planted/double crop soybean in the gulf coast region of southeastern USA [31]. The response of soybean to starter or supplemental nitrogen varies depending on location, genotype, and soil. Studies by Gan et al. [32] in China indicated that application of $50 \mathrm{~kg} \mathrm{~N} \cdot \mathrm{ha}^{-1}$ at V2 stage of development increased yield of three soybean genotypes compared to no $\mathrm{N}$ fertilizer addition.

The potential effects of fermentative degradation of rice straw and below ground residues may also be considered as a source for potential alleopathic compounds that may affect soybean development. Acetic, propionic and butyric acid may be generated from anaerobic decom-

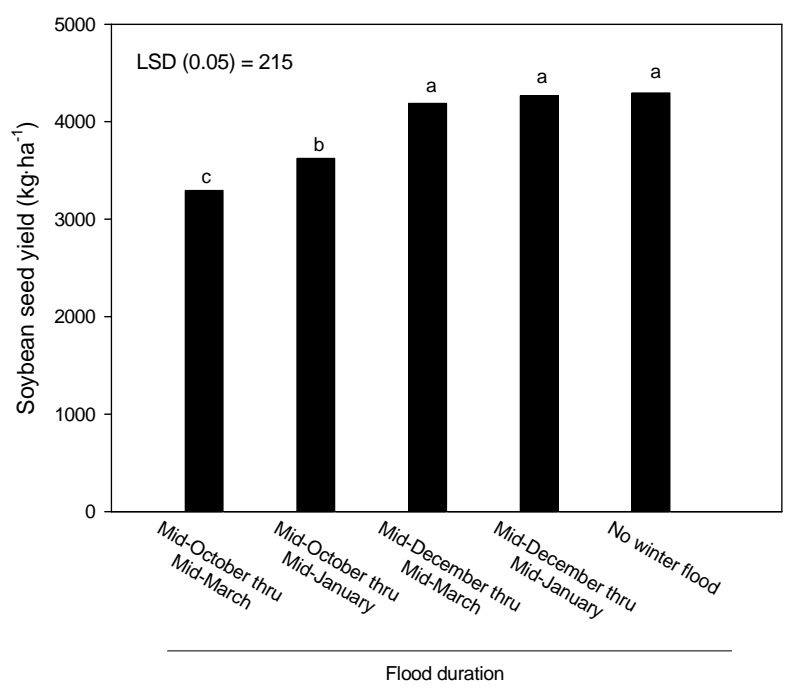

Figure 2. Seed yield of soybean crop as affected by winter flooding. Bars with the same letters are not different $(P>$ 0.05) according to LSD0.05. 
position of plant residues [33,34]. Other phenolic compounds (caffeic, vanillic, syringic and p-coumaric acids) are also associated as allelochemicals produced from rice [35]. It has been suggested by Pathak et al. [36] that incorporation of rice straw and addition of appropriate fertilization can improve subsequent wheat yield and improve soil fertility. This practice would obviate the need for burning of rice straw but enhance the potential for denitrification and $\mathrm{N}_{2} \mathrm{O}$ emissions. The trend to adopt no-till crop production is being sought in the US, thus practices to enhance rice straw degradation without tillage or burning such as winter flooding is highly desirable for a rice soybean rotation.

Overall, flooding reduced winter weed presence at time of soybean planting. The necessity for a preplant herbicide application to control existing weed vegetation would not be needed if no weeds were present at time of crop planting, thus potentially reducing costs and increasing profit margins. Winter flooding also aided in reducing rice straw residue that is capable of reducing soil temperatures and possibly delaying planting soybean into a stale seedbed of rice straw residue. The most significant impact of winter flooding was its negative impact on yield of the following soybean crop. Loss of nutrients, especially nitrogen is another possible concern, and a more critical assessment of the effects of flooding on nitrogen is warranted. Based on the soil enzyme assays, longterm flooding had significant effects on indices of soil microbial activity, although contrasting effects were observed comparing the two years. The practice of winter flooding should be reconsidered when planting soybean the next spring, as reduced crop yields can significantly reduce gross and net economic returns. Reducing the duration of flooding from mid-December to mid-March will have a less detrimental effect on soybean yield while still providing a suitable habitat for migratory waterfowl and provide a significant amount of weed control. Further research is underway to determine the specific impacts of winter flooding on soil microbes necessary for soybean nodulation and nitrogen fixation, soil nutrient availability to soybean plants, and the effect these factors have on soybean plant growth and development and subsequent soybean yield.

\section{Acknowledgements}

The authors would like to thank Efren Ford, Jay Barnett, Scott Lanford, and Earl Gordon for their assistance in conducting this research.

\section{REFERENCES}

[1] USDA United States Department of Agriculture, "National Agricultural Statistics Service," Crop Production Acreage Supplement, 2005.
http://usda.mannlib.cornell.edu/MannUsda/viewDocumen tInfo.do?documentID=1047

[2] M. E. Kurtz, C. E. Snipes, J. E. Street and F. T. Cooke Jr., "Soybean Yield Increases in Mississippi Due to Rotations with Rice," Mississippi Agricultural \& Forestry Experiment Station Bulletin, No. 994, 1993.

[3] K. D. Nelms, "Wetland Management for Waterfowl Handbook," Mississippi River Trust, Natural Resources Conservation Service, United States Fish and Wildlife Service, Stoneville.

[4] Y.-I. Kuk, N. R. Burgos and R. E. Talbert, "Evaluation of Rice By-Products for Weed Control," Weed Science, Vol. 49, No. 1, 2001, pp.141-147. doi:10.1614/0043-1745(2001)049[0141:EORBPF]2.0.CO ;2

[5] C. H. Koger, K. N. Reddy and D. H. Poston, "Factors Affecting Seed Germination, Seedling Emergence, and Survival of Texasweed (Caperonia palustris)," Weed Science, Vol. 52, No. 6, 2004, pp. 989-995.

doi:10.1614/WS-03-139R2

[6] C. H. Koger, J. E. Street and T. W. Walker, "Timing of Fall Flooding Effects on Winter Weed Emergence in Rice Production Systems," Proceedings of the Southern Weed Science Society, Vol. 57, 2004, p. 297.

[7] D. J. Boquet, "Yield and Risk Utilizing Short-Season Soybean Production in the Mid-Southern USA," Crop Science, Vol. 38, No. 4, 1998, pp. 1004-1011. doi:10.2135/cropsci1998.0011183X003800040020x

[8] L. G. Heatherly, "Early Soybean Production System (ESPS)," In: L. G. Heatherly and H. F. Hodges, Eds., Soybean Production in the Mid-South, CRC Press, Boca Raton, 1999, pp. 103-108.

[9] L. G. Heatherly, "Soybean Irrigation,” In: L. G. Heatherly and H. F. Hodges, Eds., Soybean Production in the Mid-South, CRC Press, Boca Raton, 1999, pp. 119-142.

[10] L. G. Heatherly and S. R. Spurlock, "Furrow and Flood Irrigation of Early-Planted, Early-Maturing Soybean Rotated with Rice," Crop Science, Vol. 92, No. 4, 2000, pp. 785-791.

[11] V. S. Green, D. E. Stott and M. Diack, "Assay for Fluorescein Diacetate Hydrolytic Activity: Optimization for Soil Samples," Soil Biology \& Biochemistry, Vol. 38, No. 4, 2006, pp. 693-701. doi:10.1016/j.soilbio.2005.06.020

[12] J. Schnörer and T. Rosswall, "Fluorescein Diacaetate Hydrolysis as a Measure of Total Microbial Activity in Soil and Litter," Applied and Environmental Microbiology, Vol. 43, No. 6, 1982, pp. 1256-1261.

[13] L. E. Casida Jr, "Microbial Metabolic Activity in Soil as Measured by Dehydrogenase Determination," Applied and Environmental Microbiology, Vol. 34, No. 6, 1977, pp. 630-636.

[14] M. A. Weaver, R. M. Zablotowicz, L. J. Krutz, C. T. Bryson and M. A. Locke, "Microbial and Vegetative Changes Associated with Development of a Constructed Wetland," Ecological Indicators, Vol. 13, No. 1, 2012, pp. 37-45. doi:10.1016/j.ecolind.2011.05.005

[15] R. M. Zablotowicz, K. N. Reddy, M. A. Weaver, A. Mengistu, L. J. Krutz, R. E. Gordon and N. Bellaloui, "Cover 
Crops, Tillage, and Glyphosate Effects on Chemical and Biological Properties of a Lower Mississippi Delta Soil and Soybean Yield," Environmental Research Journal, Vol. 4, No. 3-4, 2010, pp. 227-251.

[16] P. Pederson, B. Elbert, D. Pavlik and J. McGuire, "Identifying Stages of Development," In: J. McGuire, Ed., Soybean Growth and Development, University Extension Press, Ames, 2004, pp. 5-20.

[17] SAS Institute Inc., "SAS/STAT 8.2 User's Guide," Statistical Analysis Systems Institute, Cary, 2001.

[18] E. J. W Visser, L. A. C. J. Voesenek, B. B. Vartapetian and M. B. Jackson, "Flooding and Plant Growth," Annals of Botany, Vol. 91, 2003, pp. 107-109. doi:10.1093/aob/mcg014

[19] A. D. Hanson and J. V. Jacobsen, "Control of Lactate Dehydrogenase, Lactate Glycolosis, and $\alpha$-Amylase by $\mathrm{O}_{2}$ Deficit in Barley Aleurone Layers," Plant Physiology, Vol. 75, No. 3, 1984, pp. 566-572. doi:10.1104/pp.75.3.566

[20] S. Haung, H. Greenway and T. D. Colmer, "Responses of Coleoptiles of Intact Rice Seedlings to Anoxia: $\mathrm{K}^{+}$Net Uptake from the External Solution and Translocation from the Caryopses," Annals of Botany, Vol. 91, 2003, pp. 271-278. doi:10.1093/aob/mcf122

[21] J. E. Hill, D. M. Brandon, S. M. Brouder, A. U. Eke, T. E. Graus, M. A. Llagas, B. A. Lindquist and S. C. Scardaci, "Winter Flooding and Straw Management: Implications for Rice Production," Agronomy Progress Report, No. 264, University of California, Davis, 1999, pp. 5-25.

[22] D. M. Brandon, S. Brouder, D. Chaney, J. E. Hill, J. M. Payne, S. C. Scardaci, J. F. Williams and J. E. Wrysinski, "Rice Straw Management Today and Tomorrow," University of California Cooperative Extension Publication, University of California, Davis, 1995.

[23] M. Tucker-Paterson, "Response of Soil Microbial Communities and Processes to Winter Flooding," M.S. Thesis, Mississippi Valley State University, Itta Bena, 2005.

[24] F. N. Ponnamperuma, "Chemnical Kinetics of Wetland Rice Soils Relative to Soil Fertility in Wetland Soils: Characterization, Classification, and Utility," International Rice Research Institute, Manila, 1985, pp. 71-90.

[25] R. Khosla, K. L. Flemming, J. A. Delgado, T. M. Shaver and D. G. Westfall, "Use of Site-Specific Nitrogen Management Zones to Imptrove Nitrogen Management for Precision Agriculture," Journal of Soil and Water Conservation, Vol. 57, 2002, pp. 513-518.

[26] D. G. Wetterauer and R. J. Killorn, "Fallow- and Flooded-
Soil Syndromes: Effects on Crop Production," Journal of Production Agriculture, Vol. 9, No. 1, 1996, pp. 39-41. doi:10.2134/jpa1996.0039

[27] J. R. Ellis, "Post Flood Syndrome and Vesicular-Arbuscular Mycorrhizal Fungi," Journal of Production Agriculture, Vol. 11, No. 2, 1998, pp. 200-204. doi:10.2134/jpa1998.0200

[28] H. Shahandeh, L. R. Hossner and F. T. Turner, "Phosphorus Relationships in Flooded Rice Soils with Low Extractable Phosphorus," Soil Science Society of America Journal, Vol. 58, No. 4, 1994, pp. 1184-1189. doi:10.2136/sssaj1994.03615995005800040025x

[29] G. R. Safir, "Ecophysiology of VA Mycorrhizal Plants," CRC Press, Inc., Boca Raton, 1987, p. 224.

[30] R. D. Lohry and P. E. Fixen, "Will Floods Mean Return of Fallow Soil Syndrome," Fluid Journal, Vol. 2 No. 1, 1994, pp. 23-25.

[31] M. E. Starling, C. W. Wood and D. B. Weaver, "Starter Nitrogen and Growth Habit Effects on Late-Planted Soybean," Agronomy Journal, Vol. 90, No. 5, 1998, pp. 658662. doi:10.2134/agronj1998.00021962009000050015x

[32] Y. Gan, I. Stulen, H. van Keulen and P. J. C. Kuiper, "Effect of Nitrogen Top-Dressing at Various Reproductive Stages on Growth, Nitrogen Fixation and Yield of Three Soybean (Glycine max L. Merr.) Genotypes," Field Crops Research, Vol. 80, No. 2, 2003, pp. 147-155. doi:10.1016/S0378-4290(02)00171-5

[33] V. L. Cochran, L. F. Elliot and R. I. Papendick, "The Production of Phytotoxins from Surface Crop Residues," Soil Science Society of America Journal, Vol. 41, No. 5, 1977 , pp. 903-908. doi:10.2136/sssaj1977.03615995004100050018x

[34] K. J Janovicek, T. J. Vyn, R. P Voroney and O. B. Allen, "Early Corn Seedling Growth to Acetic Acid, Propionic Acid and Butyric Acid," Canadian Journal of Plant Science, Vol. 77, No. 3, 1997, pp. 333-337. doi:10.4141/P96-122

[35] A. N. Seal, T. Haig and J. E. Pratley, "Evaluation of Putative Allelochemicals in Rice Root Exudates for Their Role in the Suppression of Arrowhead Root Growth," Journal of Chemical Ecology, Vol. 30, No. 8, 2004, pp. 1663-1678. doi:10.1023/B:JOEC.0000042075.96379.71

[36] H. Pathak, R. Singh, A. Bhatia and N. Jain. "Recycling of Rice Straw to Improve Wheat Yield and Soil Fertility and Reduce Atmospheric Pollution," Paddy and Water Environment, Vol. 4, No. 2, 2006, pp. 111-117. doi:10.1007/s10333-006-0038-6 